IRSH 60 (2015), pp. I6I-I9I doi:10.10I7/S002085901 5000I76

(C) 2015 Internationaal Instituut voor Sociale Geschiedenis

\title{
The Politics of Ambiguity: Conditional Manumission, Labor Contracts, and Slave Emancipation in Brazil (I 8 50s-I 888$)^{*}$
}

\author{
SidNEY CHA L H OUB \\ Instituto de Filosofia e Ciências Humanas, Universidade Estadual de \\ Campinas - UNICAMP \\ CEP 13083-896, Campinas, São Paulo, Brasil
}

E-mail: chalhoub@unicamp.br

\begin{abstract}
Although it seems that slaves in Brazil in the nineteenth century had a better chance of achieving freedom than their counterparts in other slave societies in the Americas, studies also show that a significant proportion of manumissions there were granted conditionally. Freedom might be dependent on a master's death, on a master's daughter marriage, on continued service for a number of years, etc. The article thus focuses on controversies regarding conditional manumission to explore the legal and social ambiguities between slavery and freedom that prevailed in nineteenth-century Brazilian society. Conditional manumission appeared sometimes as a form of labor contract, thought of as a situation in which a person could be nominally free and at the same time subject to forms of compulsory labor. In the final crisis of abolition, in $1887-1888$, with slaves leaving the plantations in massive numbers, masters often granted conditional manumission as an attempt to guarantee the compulsory labor of their bonded people for more years.
\end{abstract}

\section{INTRODUCTION}

The historical process that made liberalism, old and new, the guiding ideology of Western societies brought with it the invention of new forms of unfree labor. Liberalism and free labor, ancien regime and serfdom and/or slavery are no longer unproblematic pairs of historical intelligibility. The first half of the nineteenth century did not see the weakening of slavery in the Americas at all, but just the partial relocation of it. The institution of slavery gradually disappeared in the British and French Caribbean while it

* This article is a sequel to Sidney Chalhoub, "The Precariousness of Freedom in a Slave Society (Brazil in the Nineteenth Century)", International Review of Social History, 56 (201 I), pp. 405-439. A first draft was written while I was a fellow at IGK Work and Human Lifecycle in Global History, Humboldt Universität, Berlin, January-July 2013. Research in Brazil was funded by the Conselho Nacional de Pesquisa $(\mathrm{CNPq})$ and the Fundação de Amparo à Pesquisa do Estado de São Paulo (FAPESP). My thanks to Michael Hall and Robert Slenes for their critical comments and corrections of my English. 
became stronger in Brazil, Cuba, and the US South. ${ }^{\mathrm{I}}$ In the second half of the nineteenth century, as the nightmare of an international order based on slavery was finally defeated in the American Civil War, ${ }^{2}$ there emerged extremely aggressive racist ideologies that justified Western imperial expansion and the persistence of forced labor in Africa and elsewhere. Actually, it boggles the mind to think that for so long it seemed possible to conceive of the nineteenth century as a time of transition from slavery to freedom, from bondage to contractual and/or free labor. In fact, contract labor, however diverse in its forms, was often thought of as a form of coerced labor, with workers having to submit to debt bondage and various forms of criminal sanction for breach of contract. ${ }^{3}$

In this article, I focus on controversies regarding conditional manumission to explore the legal and social ambiguities between slavery and freedom that prevailed in nineteenth-century Brazilian society. In doing so, I suggest that the sharp distinction between slavery and freedom is an ideological construct that makes it difficult for us to re-imagine the experience of Africans and their descendants that were enslaved in Brazil and elsewhere. Furthermore, the tale of slave emancipation as a watershed event in the history of humanity prevents us from seeing the legacy of slavery and the burden of so-called "freedom" past and present that workers in so many parts of the world have had to bear until today. After all, as was the case during the times of Atlantic slavery, the logic of present-day world capitalist interactions continues to rely on the fact that somewhere, out of sight and out of mind, there are lives that are unworthy and expendable, available to be put to labor under very harsh conditions.

A couple of further introductory remarks are in order to situate readers regarding the history and historiography of Atlantic slavery and slave emancipation in general, and in Brazil in particular, as well as to clarify

I. For a comparative overview of this process see, for instance, Dale W. Tomich, Through the Prism of Slavery: Labor, Capital, and World Economy (Lanham, MD, 2004), pp. 56-7I.

2. For the centrality of slavery to the geopolitics and international political economy up until the American Civil War, see Rafael de Bivar Marquese and Tâmis Peixoto Parron, "Internacional escravista: a política da Segunda Escravidão", Topoi, I 2 (July-December 201 I), pp. 97-1 17.

3. The literature on the subject is vast and growing; see, for instance, Robert J. Steinfeld, The Employment Relation in English \& American Law and Culture, I350-I870 (Chapel Hill, NC [etc.],199I); Amy Dru Stanley, From Bondage to Contract: Wage Labor, Marriage, and the Market in the Age of Slave Emancipation (Cambridge, 1998); Douglas Hay and Paul Craven (eds), Masters, Servants, and Magistrates in Britain and the Empire, I562-1955 (Chapel Hill, NC [etc.], 2004); Marcel van der Linden, Workers of the World: Essays Toward a Global Labor History (Leiden, 2008); Alessandro Stanziani, "Introduction: Labour Institutions in a Global Perspective, from the Seventeenth to the Twentieth Century", International Review of Social History, 54 (2009), pp. 35 I-358; Marcel van der Linden and Prabhu Mohapatra (eds), Labour Matters: Towards Global Histories. Studies in Honour of Sabyasachi Bhattacharya (New Delhi, 2009); Marcel van der Linden (ed.), Humanitarian Intervention and Changing Labor Relations: The Long-term Consequences of the Abolition of the Slave Trade (Leiden, 20I I). 
further my argument regarding conditional manumission in the more general historical landscape sketched above. Brazil was the last country in the Americas to abolish slavery, doing so in I 888, thus after the United States, which achieved it in I 865, and Cuba, in I 886. It did so after a long, protracted legislative process, which had landmark laws in I 850 (abolition of the African slave trade), i 87 I (a law declaring free the offspring of slave mothers born thereafter), I 885 (freedom for sexagenarian slaves) and, finally, full abolition on I 3 May i 888 . The abolition decree did not determine any compensation to slave owners, neither did it establish or was followed by public policies devised to aid the approximately 700,000 people, then freed, in the transition to their new condition.

The historiography of slave emancipation in the Americas has been slow to recognize some key commonalities regarding emancipation processes in different countries. A brief comparison between the United States and Brazil may help to bring the subject and the argument of this article into sharp relief. Apparently, the two cases could not offer a more striking contrast: in the former country, a violent civil war and an abrupt ending to slavery; in the latter, a long and protracted process that spanned almost four decades until abolition. However, a common thread connects both histories: worlds of slavery and "free" labor coexisted for a long period in both countries, and the interplay of these different labor regimes configured much of the legal contradictions and social conflicts that shaped the experience of people of African descent, slave and free.

It is common to conceive of the process of slave emancipation in the United States as consisting of two very distinct phases. ${ }^{4}$ The "first emancipation", associated with the repercussions of the American Revolution, consisted of gradual abolition laws that provided for the freedom of the children of those enslaved, normally when they reached a certain age in adulthood. The states of Pennsylvania, Rhode Island, Connecticut, New York, and New Jersey enacted such statutes between 1780 and I 804 . This so-called "first emancipation" established the division and the sectional conflict that led to the American Civil War, thus bringing about the second, "revolutionary" emancipation, in I 865, which was such a dramatic event that it tends to obliterate somewhat the previous process of emancipation. Furthermore, the history of the conflict between the "free-labor" North and the "slave-labor" South appears to make difficult the proper appreciation of how the two processes coexisted and connected.

For example, the confirmation of the right of recapture of allegedly fugitive slaves by the Supreme Court in I 842 (based upon the Fugitive Slave Law of 1793) and the enforcement of the Fugitive Slave Law of I 850 in the 
northern states made clear how vulnerable was the freedom of people of African descent also in the North. As Steven Hahn says in his very insightful essay that I draw upon here, "as slaves disappeared officially in the states of what we call the North [as a result of first emancipation], they were appearing [there] unofficially as fugitives from the states of the South". Hahn concludes that it makes more sense to think of a picture "in which slavery - for the duration of the antebellum period - was national rather than sectional, in which freedom for African Americans was highly contingent $[\ldots]$ and in which abolition and antislavery [...] were struggling, with successes and failures, to limit the prerogatives of slaveholders".

In the case of Brazil, the politics of domination over slaves depended upon masters achieving a finely tuned balance between physical punishment and the positive incentive of manumission. However difficult, it seems that manumission was a meaningful possibility for Brazilian slaves, a hope renewed periodically by the experience of seeing a partner manumitted and by the observation of the significant presence, in the general population, of free and freed people of African descent, many of them heirs of freedoms obtained in previous generations. As I argued in a preceding article published in this journal, ${ }^{6}$ nonetheless, the worlds of slavery and freedom were one and the same world of labor exploitation and control - as was also the case, however differently, in the United States. Going in a similar direction, Rebecca Scott and Jean Hébrard have pointed out in a recent study that the precariousness of freedom was, as long as slavery still existed, a shared experience for free and freed people of African descent in the Americas. ${ }^{7}$ In Brazil, they were often enslaved illegally, received conditional manumission, had their freedoms revoked, were arrested on suspicion of being fugitive slaves, and so on.

There are three intertwined senses in which I conceive of conditional manumission as a politics of ambiguity in the context of Brazilian slave emancipation. First, regarding the realm of lived experience, masters and conditionally manumitted slaves were often unsure of what conditional manumission entailed in terms of expected behavior, prerogatives, and obligations. Therefore, they struggled to define it in daily relations, in situations often exposed at length in civil and criminal court cases. ${ }^{8}$ This is an aspect of the question not approached in depth here. Second, conditional manumission was a legal conundrum, a difficult challenge to judicial authorities

5. Ibid., p. I 3; see also, on "the precarious terrain of northern freedom", Ira Berlin, Generations of Captivity: A History of African-American Slaves (Cambridge, MA [etc], 2003), pp. 234-236.

6. Chalhoub, "The Precariousness of Freedom in a Slave Society".

7. Rebecca Scott and Jean Hébrard, Freedom Papers: An Atlantic Odyssey in the Age of Emancipation (Cambridge, MA [etc], 20I2).

8. I analyzed some cases in Sidney Chalhoub, Visões da liberdade: uma história das últimas décadas da escravidão na Corte (São Paulo, 1990), pp. I22-I42. 


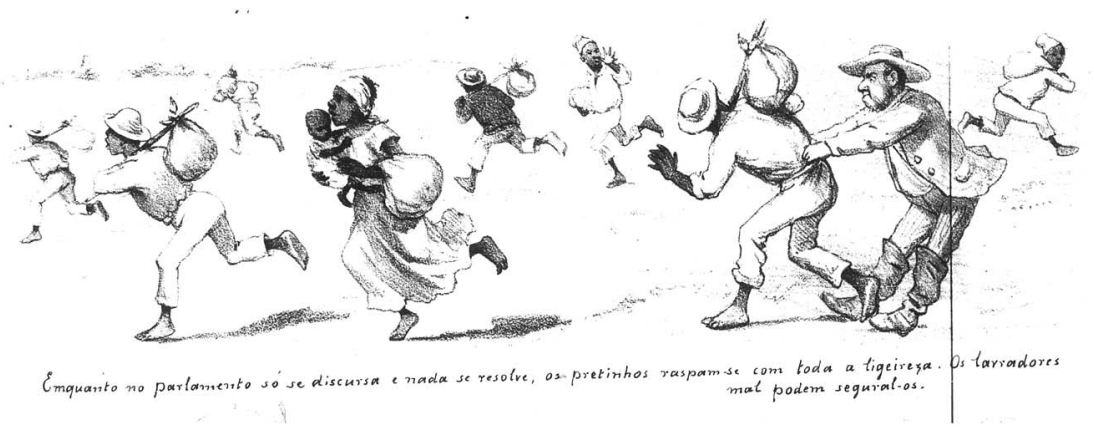

Figure I. Revista Illustrada, I 2th year, no. 466 (Rio de Janeiro, 30 September I887), detail on p. $4 .^{9}$ Translation of cartoon text: "While in parliament they make speeches and do not decide anything, blacks run away very quickly. The planters are not able to stop them.”

engaged in interpreting its meanings with regard to the status of children of conditionally manumitted mothers, to obligations of rendering service, to alleged motives that allowed it to be revoked, to inheritance rights, and so forth. Third, and this follows from the two previous observations, historical actors appropriated conditional manumission differently, interpreting its ambiguous and uncertain nature according to circumstances and struggles about emancipation and the shaping of labor relations in its aftermath.

The final crisis of slavery in Brazil involved episodes of massive slave flight from coffee plantations - perhaps one should not hesitate to call it "a general strike" ${ }^{10}$ - apparently motivated or intensified, in part, by the government's plan to enact a law that would declare abolition together with the obligation of two, three, or more years of further service by freed people. The idea appeared a way of turning the then widely practised strategy by planters (of granting conditional manumission to their slaves in the hope of guaranteeing their forced labor for more years) into an official policy. However, in the spring and summer of $1887-1888$, roughly from September to April, slaves "voted" against the projected law, "conditional manumission" for all, with their feet.

9. The Revista Illustrada was perhaps the most famous illustrated periodical published in the city of Rio in the nineteenth century. It acquired great prominence during the abolitionist campaign in the I880s. Angelo Agostini (1843-1910), an Italian artist who had probably arrived in Brazil in I 859 , founded it in 1876 and was its director for the next thirteen years. For a detailed study of Agostini’s life and art, see Marcelo Balaban, Poeta do lápis: sátira e política na trajetória de Angelo Agostini no Brasil imperial (I864-I888) (Campinas, 2009).

Io. Steven Hahn draws inspiration from W.E.B. Du Bois, who described the Southern slaves' flight towards freedom and service to the Federal army during the Civil War as a "general strike"; see Hahn, The Political Worlds of Slavery and Freedom, ch. 2, entitled "Did We Miss the Greatest Slave Rebellion in Modern History?”. For the reference to Du Bois' idea of a "general strike”, see pp. I06-I Iо. 


\section{SLAVERY AND FREEDOM}

An important characteristic of slavery in Brazil was that it depended heavily on the slave trade to continue to exist. In this sense, it offers a sharp contrast with slavery in the United States. From the is 60 s to i 850 , more than 4 million and 800,000 enslaved Africans were shipped to Brazil; in contrast, from the seventeenth century to I 808 about 450,000 enslaved Africans arrived in North America. Therefore, ten times more Africans went to Brazil than to the USA. It is also remarkable that 42 per cent of the total number of Africans taken to Brazil arrived there in the first half of the nineteenth century (more than 2 million people). ${ }^{\text {II }}$ Recent historiography calls the period "second slavery": decline in the British and French Caribbean; expansion in Cuba, Brazil, and southern USA. ${ }^{\mathrm{I} 2}$ As a consequence, when this intense slave trade was ended by the mid-century, Brazilian slavery was very "Africanized", so to speak. ${ }^{\mathrm{I}}$ In the coffeegrowing areas of the provinces of Rio de Janeiro and São Paulo, it was common to have approximately 80 per cent of the slave labor force in the plantations composed of African-born people. ${ }^{14}$ Rio de Janeiro, the capital of the Brazilian Empire (I 822-I 889), had a population of 266,000 people in I 849; more than i I0,000 inhabitants were slaves, or 4 I.2 per cent of the total population (this was the largest urban slave population in the Americas at any time; just as a point of contrast, there were I 5,000 slaves in New Orleans in I 860). About 60 per cent of the I I0,000 slaves living in Rio were Africans. ${ }^{\text {Is }}$

Throughout the first half of the nineteenth century, although there was no national census in the whole period, slaves constituted about 30 to 40 per cent of the total population of Brazil, according to contemporary estimates. In I 872, when the first national census took place, 22 years after the cessation of the African trade, slaves constituted is per cent of the population - that is, about I.5 million people in a total population of

I I. Data compiled from www.slavevoyages.org, accessed on 6 September 2010.

1 2. Tomich, Through the Prism of Slavery, pp. 56-71.

I3. Robert Slenes, “'Malungu, ngoma vem!': África coberta e descoberta no Brasil”, in Nelson Aguilar (ed.) Mostra do Redescobrimento: Negro de Corpo e Alma - Black in Body and Soul (São Paulo, 2000), pp. 2 I 2-220; Robert Slenes, Na senzala, uma flor: esperanças e recordações na formação da família escrava - Brasil sudeste, século XIX (Rio de Janeiro, 1999).

I4. Ricardo Salles, E o Vale era o escravo. Vassouras, século XIX. Senhores e escravos no coração do Império (Rio de Janeiro, 2008), p. 200; Ricardo Pirola, Senzala insurgente: malungos, parentes e rebeldes nas fazendas de Campinas (I832) (Campinas, 201 I), p. 63. According to Pirola, considering only adult slaves, Africans represented 93 per cent of the slave population in Campinas, province of São Paulo, in the I83os.

i 5. Chalhoub, Visões da liberdade, pp. I86-1 87; for comprehensive studies of urban slavery in Rio, see Mary Karasch, Slave Life in Rio de Janeiro: 1808-1850 (Princeton, NJ, I987) and Luiz Carlos Soares, $O$ 'Povo de Cam' na capital do Brasil: a escravidão urbana no Rio de Janeiro do século XIX (Rio de Janeiro, 2007). 
Io million. ${ }^{16}$ The slave population had decreased sharply beginning in I 850 , due to the cessation of the slave trade, high mortality rates (a cholera epidemic in 1855-1856 was particularly devastating among slaves), low birth rates, and significantly high manumission rates. In the I 850 s through the i870s, a slave labor force for coffee plantations was guaranteed by means of an intense internal trade that shifted bonded people from smaller to larger properties, from the interior to plantation areas nearer the coast, and from the north and south of the country to the provinces of Rio de Janeiro and São Paulo. ${ }^{17}$

Relatively high manumission rates meant that there was always a significant number of free and freed people of color in the Brazilian population. Thus, according to the census of $\mathrm{I} 872,73.7$ per cent of blacks and pardos (people of mixed blood) living in Brazil were free. ${ }^{18}$ In the United States, in I 860, no more than I I per cent of the population of African descent was free, which includes data from the northern states, where slavery had officially disappeared and 99 per cent of the colored population was registered as free. ${ }^{19}$ Therefore, in the case of Brazil, it is somewhat misleading to think of a sharp contrast between slavery and post-emancipation. Although abolition came only in I 888 and still liberated about 700,000 captives, at all times a significant number of persons achieved freedom in Brazilian society, thus also giving rise to a large population of freeborn people of color.

Heavy dependence on the African trade to maintain and expand the slave labor force in the plantations posed a serious political problem for the Brazilian government in the decades following Independence (obtained from the Portuguese in 1822). Under pressure from the British, the government enacted a law to abolish the African trade in November I 83 I. However, the trade continued illegally until the early i 850 , resulting in approximately 750,000 Africans being smuggled into the country and enslaved in the period. The legacy of two decades of the contraband slave trade was manifold, ranging from challenges to the security of slave property thus acquired to a widespread practice of illegal enslavement that threatened and rendered vulnerable the liberty of free and freed people of African descent in general. ${ }^{20}$

16. Nelson de Castro Senra, História das estatísticas brasileiras (Rio de Janeiro, 2006), I, pp. 4I 8-4I9, 423; for the first census see Diretoria Geral de Estatística, Recenseamento geral do Brazil de 1872, I: Quadros gerais. Recenseamento da população do Imperio do Brazil a que se procedeu no dia $\mathrm{I}^{\circ}$ de agosto de $\mathrm{i} 872$ (Rio de Janeiro, I 876 ).

17. Robert Slenes, "The Brazilian Internal Slave Trade, I850-1888: Regional Economies, Slave Experience, and the Politics of a Peculiar Market", in Walter Johnson (ed.), The Chattel Principal: Internal Slave Trades in the Americas (New Haven, CT [etc.], 2004), pp. 325-370.

18. Senra, História das estatísticas brasileiras, p. 423.

19. Berlin, Generations of Captivity, pp. $278-279$.

20. Beatriz Mamigonian, "O direito de ser africano livre: os escravos e as interpretações da lei de I 83 I", in Silvia Lara and Joseli Mendonça (eds), Direitos e justiças no Brasil. Ensaios de história 
The cessation of the slave trade brought new challenges to the politics of domination under Brazilian slavery. Traditionally, the control of Brazilian slaves had relied heavily on the combination of constant new African arrivals with the occurrence of relevant rates of access to manumission. Therefore, the continuation of the slave trade guaranteed the replacement of a labor force that had its numbers constantly reduced by manumission, appalling death rates, and relatively low birth rates. The end of the African trade left the children born of slave mothers as the only remaining source of bonded people in the country. The reproduction of slavery by means of the bondage of children born of slave wombs was a common characteristic of modern slavery in Western societies and made the politics of slave emancipation a heavily gendered subject everywhere. New World regimes adopted the ancient Roman rule of assigning to the child the civil status of the mother probably as a consequence of the growing importance of the nuclear family as a property-owning entity, thus making it necessary that the masters' offspring by slave women be excluded from any inheritance claims, except by manumission and express recognition of paternity by the master. ${ }^{21}$

The principle that the condition of the child followed the mother's acquired different political meanings depending on time and place. Abolitionist movements in the nineteenth century dwelt extensively on the subject of the separation of mothers and children. The theme was inevitable as mothers became essential in the construction of national ideologies, key figures in the education of males to be invested with political rights and power to lead the nation. The preoccupation with the education of women and their influence on children made the routine separation of slave mothers and their children as a result of everyday business transactions pertaining to slavery a horror to inspire more than a handful of romantic poets and fiery politicians. Gradual emancipation legislation based on the idea of slave mothers giving birth to free children could be found in several countries - as for example in the Moret law in Cuba in 1870 and the Free Womb law in Brazil in $1871 .^{22}$

The end of the slave trade in the i 850 s seems to have brought with it a sharp politicization of the theme of children born of slave mothers who had

social (Campinas, 2006), pp. I29-160; idem, "O estado nacional e a instabilidade da propriedade escrava: a lei de i83 I e a matrícula dos escravos de i872", Almanack, 2 (201 I), pp. 20-37; Chalhoub, "The Precariousness of Freedom in a Slave Society"; idem, A força da escravidão: ilegalidade e costume no Brasil oitocentista (São Paulo, 20I 2).

2 I. Gwyn Campbell, Suzanne Miers, and Joseph Miller, "Women in Western Systems of Slavery: Introduction", Slavery \& Abolition: A Journal of Slave and Post-Slave Studies, 26 (2005), p. I69. 22. Camillia Cowling, Conceiving Freedom: Women of Colour, Gender, and Abolition of Slavery in Havana and Rio de Janeiro (Chapel Hill, NC, 2013); Joseph Dorsey, "Women Without History: Slavery and the International Politics of partus sequitur ventrem in the Spanish Caribbean", Journal of Caribbean History, 28 (1994), pp. I65-207; Jessica Millward, "That All Her Increase Shall Be Free': Enslaved Women's Bodies and the Maryland i 809 Law of Manumission", Women's History Revierw, 2 I (20I2), pp. 363-378. 
received conditional manumission (statuliberi, as they were described, resorting to the expression present in legal codes pertaining to ancient Rome). Although, as already mentioned, the rate of manumission in Brazil was relatively high in comparison with other contemporary slave societies, recent studies show that in the various samples collected, from different locations and periods, typically 30 to 40 per cent of freedoms were granted conditionally. Freedom might be dependent on a master's death, on a master's daughter marriage, on continued faithful service for a number of years, etc. ${ }^{23}$ Let us suppose that a slave woman was granted a letter of manumission upon the condition of continuing to serve her master faithfully for a number of years. After the letter was granted, perhaps even entered into a notary public record book, and before the years of service were fulfilled, the slave woman became pregnant and gave birth to a child. Was the child, born to a conditionally manumitted woman, slave or free? Riddles of this type provoked much debate in Brazil in the i 850 and I 860 s. $^{24}$ Following such controversies, in jurisprudence and in legal cases, allow us to gain insights into struggles about how to define important concepts pertaining to non-slavery spheres of labor, such as the idea of contract labor, as well as into the expectations of masters, employers, and workers during times of deep changes and uncertainties in labor relations.

\section{CONDITIONAL MANUMISSION AND LABOR CONTRACTS}

During the nineteenth century, there was no civil code in Brazil, nor was there a "black code" or any other specific body of laws pertaining to slavery. Ordinary laws, Portuguese ordinances dating from colonial times, and different legal codes pertaining to ancient Rome regulated legal issues in relation to bondage. ${ }^{25}$ The strong relevance of ancient Roman codes for

23. Studies about manumission in Brazil are numerous, and growing steadily. See, for instance, regarding conditional manumission, Peter Eisenberg, "Ficando livre: as alforrias em Campinas no século XIX", in idem, Homens esquecidos: escravos e trabalhadores livres no Brasil, séculos XVIII e XIX (Campinas, I989), pp. 255-3 I4; Manolo Florentino, "Sobre minas, crioulos e a liberdade costumeira no Rio de Janeiro, I789-1871", in idem (ed.), Tráfico, cativeiro e liberdade. Rio de Janeiro, séculos XVII-XIX (Rio de Janeiro, 2005), pp. 33 I-359. For recent surveys of the literature on Brazilian slavery that show the centrality of the theme of manumission, see Hebert Klein and Francisco Vidal Luna, Slavery in Brazil (New York, 2010), especially ch. 9; Robert Slenes, "Brazil", in Robert Paquette and Mark Smith, The Oxford Handbook of Slavery in the Americas (Oxford, 2010), pp. I I I-I33; Jean Hébrard, "L’Esclavage au Brésil. Le Débat Historiographique et ses Racines", in idem (ed.), Brésil: Quatre Siècles d'Esclavage. Nouvelles Questions, Nouvelles Recherches (Paris, 20I 2), pp. 7-63; Herbert Klein and João Reis, "Slavery in Brazil”, in José Moya (ed.), The Oxford Handbook of Latin American History (Oxford [etc.], 20 I I), pp. I 8 I-2 I I.

24. For a previous discussion of this issue with different analytical purposes, see Chalhoub, Visões da liberdade, pp. I 22-1 30.

25. Keila Grinberg, O fiador dos brasileiros: cidadania, escravidão e direito civil no tempo de Antonio Pereira Rebouças (Rio de Janeiro, 2002); Mariana Paes, "Sujeitos da história, sujeitos de 
Brazilian slavery may have been a consequence of the importance of manumission in both slave societies and the problem of dealing with different forms of transition to freedom and integration of freed persons into society. ${ }^{26}$ Yet, manumission in ancient Greek and Roman contexts, and the ways of dealing with the liberation of certain individuals and their process of integration into the polity, happened in societies that would continue to operate as slave-based societies. ${ }^{27}$ Resort to Roman law in legal debates regarding slavery in the 1850 s and I 860 s in Brazil, nonetheless, was embedded in the struggles pushing towards emancipation. Thus, for instance, the subtleties concerning the uncertain status of people who had received conditional manumission acquired new political meanings beginning in the I 850 , however traditional had been the practice of thinking Brazilian slavery in terms of Roman law.

In I 867, within an international context of increasing isolation of the remaining slave regimes in the aftermath of the defeat of the South in the American Civil War, a Brazilian lawyer, J. Caroatá, decided to organize a compilation of court decisions and other documents pertaining to questions of Brazilian slavery that had been highly controversial. ${ }^{28}$ His explicit aim was to collect materials that would be useful to lawyers and judges who had to deal routinely with slavery and appeals for freedom in court. Furthermore, he argued that the decisions gathered were "regulated by moral principles that [...] conceded ample prerogatives and advantages in favor of freedom". ${ }^{29}$ In other words, Caroatá recognized from the outset the political motivation of his efforts, which was to forward the cause of slave emancipation. Although the volume addressed twenty-six different legal questions, the first of them, and the one most lengthily documented, occupying about one-quarter of the whole book, concerned the condition of children born of slave women who had been granted conditional manumission.

Among the documents offered on the subject, there appeared the debates held in the Institute of Brazilian Lawyers (Instituto da Ordem dos

direitos: personalidade jurídica no Brasil escravista (I 860-88)" (Master's thesis in Law, Universidade de São Paulo, 2014).

26. However, a recent study did not find any resort to Roman codes in slavery-related civil suits in eighteenth-century Minas Gerais; Fernanda Pinheiro, "Em defesa da liberdade: libertos e livres nos tribunais do Antigo Regime português (Mariana e Lisboa, I720-I 8 I9)" (Doctoral dissertation in History, Universidade Estadual de Campinas [UNICAMP], 20I3).

27. For groundbreaking comparative views on ancient Roman and US slavery see: Moses I. Finley, "Between Slavery and Freedom", Comparative Studies in Society and History, 6 (1964), pp. 233-249; idem, Ancient Slavery and Modern Ideology (London, I980); see also Marcus Wood, The Horrible Gift of Freedom: Atlantic Slavery and the Representation of Emancipation (Athens, $\mathrm{OH}$ [etc.], 2010), pp. 44-50.

28. J.P.J. da S.C. [Caroatá], Apanhamento de decisões sobre questões de liberdade, publicadas em diversos periodicos forenses da Corte (Bahia, I867).

29. Ibid., p. 4. All translations from Portuguese are mine. 
Advogados Brasileiros, IAB) from October to December, I $857 .^{30}$ Some members of the Institute, such as Caetano Soares and Perdigão Malheiro, argued forcefully that the children of conditionally manumitted slave mothers were born free. They started with the assumption that the slave who had been granted conditional liberty became free from that moment onwards, irrespective of the limitations imposed on his or her freedom due to the obligation of rendering further services. Therefore, given the Roman principle of partus sequitur ventrem, the offspring of conditionally freed women (statuliberi) were born of free wombs.

The question was framed at the Institute in a way that presented a further complication. The imaginary master who granted freedom to a slave woman had done so in a last will and testament, therefore bequeathing her services as a conditionally freed person to a third party upon his death. The members of the Institute had to decide whether the third party enjoying the services of the statuliber became the proprietor of the fruits of the reproductive labor of the woman, inasmuch as the fruits of trees and the offspring of animals belonged to those who had formal temporary rights over them. Here again, both Soares and Malheiro found precedent in Roman law to maintain that, in contrast to the cases of plants and animals, the children of statuliberi slaves were not fruit, so they did not become the property of those with usufruct rights to the women's services. In addition, differently from the situation of their mothers, whose labor force belonged temporarily to the third party who had usufruct rights over them, the children were not under the obligation of rendering services - that is, they were ingênuos, or perfectly free, from the moment of their birth. ${ }^{3 \mathrm{I}}$

Soares and Malheiro found a formidable adversary in the President of the Institute, Teixeira de Freitas, perhaps the most respected interpreter of Roman law in the country at the time. The President suggested that Soares and Malheiro had not based their opinion on the rigorous interpretation of Roman law, but rather on the application of tenets derived from natural law that could not apply to a society in which slavery still existed. The fact that slavery continued to exist in Brazil was to be lamented; however, seeking to rule a slave society according to legal principles that were incompatible with it seemed contradictory and pointless. Freitas analyzed the Roman legal text

30. Ibid., pp. I 2-37; for a detailed study of these debates and others regarding emancipation in the IAB, see the excellent book by Eduardo Spiller Pena, Pajens da Casa Imperial: jurisconsultos, escravidão e a lei de I87I (Campinas, 200I).

31. Caroatá, Apanhamento, pp. I 2-13, 17. Legally, in nineteenth-century Brazil, the offspring of free and freed women were called ingênuos (as opposed to the offspring of bonded women, who were slaves). According to the Constitution of 1824 , ingênuos, regardless of color, could have access to political rights when they came of age and if they met the income requirements established by the Constitution. After the Free Womb Law (I87I), the word ingênuos was commonly used to refer to the thereafter freeborn children of slave women. 


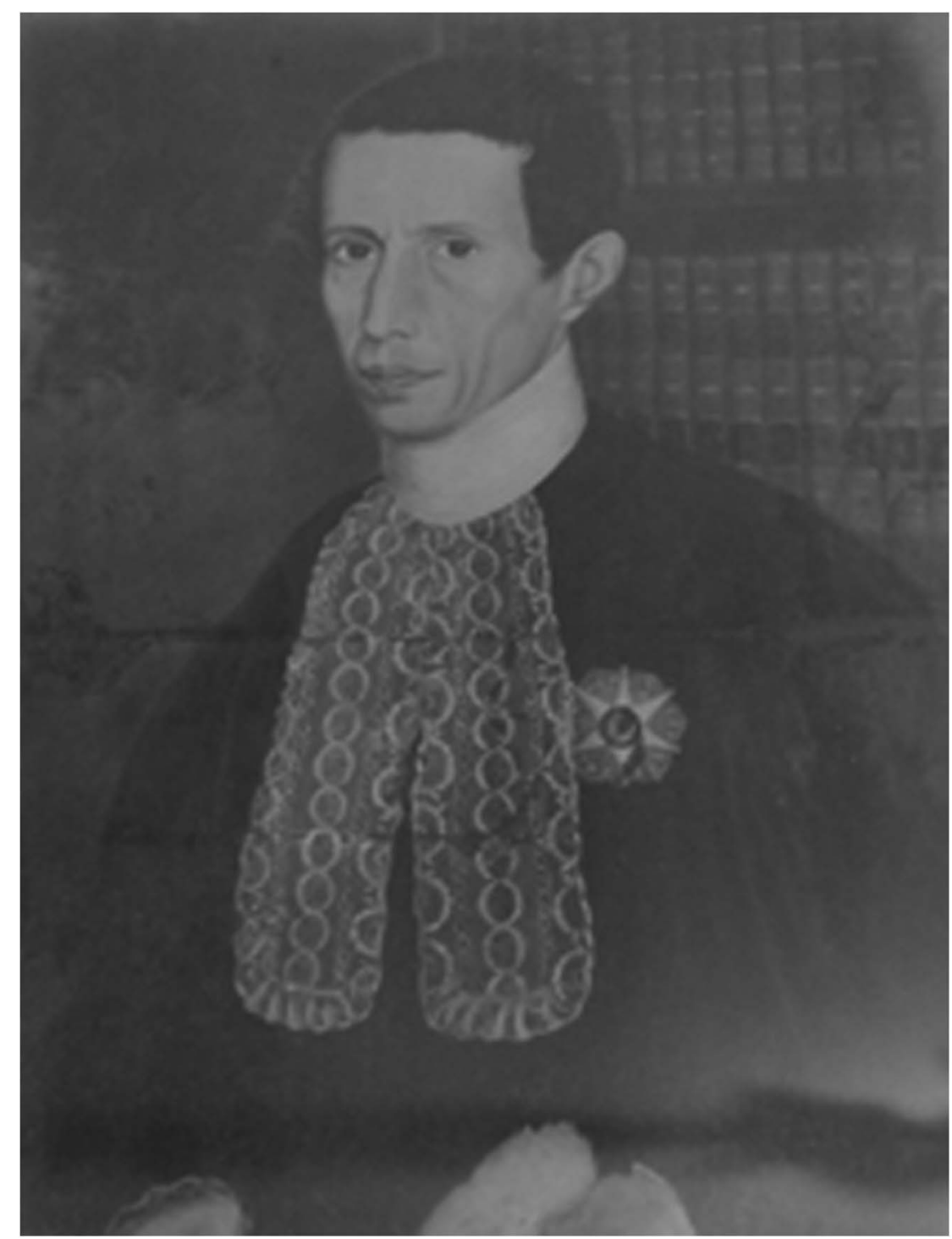

Figure 2. Caetano Soares.

Instituto dos Avogados Brasileiros; http://wwrw.iabnacional.org.br/article.php3?id_article $=203$ I $E$ var_recherche $=$ escravos

that served as the source for the contention that the children of statuliberi women did not become the property of a third party that had usufruct rights to their services. According to him, the purpose of the legal text cited was to defend the idea that the children belonged to the proprietor, or to his 
heirs, not to the third party who was enjoying the woman's services for a period. In other words, either Soares and Malheiro did not know what they were talking about, or they had purposefully distorted the meaning conveyed in a legal source that did not uphold the right to freedom of the children of statuliberi women. The exchange promptly turned sour, with Teixeira de Freitas arguing that, according to Roman law, the statuliberi remained in bondage for as long as there was a pending condition regarding their freedom; consequently, the children of conditionally manumitted women were slaves because their status followed that of their mothers. ${ }^{32}$

The nature of conditional manumission became a central aspect of the debates that followed. Teixeira de Freitas thought that manumission was a donation, a unilateral act originating exclusively from the master's will. Therefore it seemed incorrect to think of so-called conditional manumission as truly involving a condition because "a condition depends on an uncertain fact, on chance or on the will of man; in the case at hand the slave exercises no will"; ${ }^{33}$ that is, the services had to be performed regardless of his or her decision to do so. In other words, the obligation to render services meant the continuation of bondage itself. He proceeded to say that slavery could not be properly compared with other labor regimes. Referring to the law of I 837 that regulated labor contracts for supposedly free workers in Brazil, Freitas argued that laborers entered into such contracts knowing that there were obligations to fulfill and that breach of contract would entail indemnification and penal sanctions. In contrast, slaves, including the statuliberi, could not refuse to perform services, nor were there applicable sanctions or compensation to deal with the situation. In sum, because the statuliberi had no space for choice, conditional manumission could not be compared to a labor contract that workers entered into voluntarily. ${ }^{34}$

Apparently aware that continuing the discussion on the terrain of Roman law did not seem promising for their purposes, Soares and Malheiro attempted to distance themselves from the idea that they proposed to solve the problem by merely seeking the right precedent in ancient codes.

\footnotetext{
32. Caroatá, Apanhamento, pp. I4-7.

33. Ibid., p. I7.

34. Ibid., pp. I 8-20. This contrast between slavery and labor contracts highlighted by Freitas at the same time also implied a proximity between them, especially in the case of conditional manumission: both of them involved a high degree of obligation. Peter Eisenberg had noticed this similarity between conditional manumission and labor contracts; Eisenberg, "Ficando livre", passim. Henrique Espada Lima has been studying systematically the "rental service contracts" made by freed persons to pay for their freedom. These contracts were made within the realm of the law of 1837 and, later, of the law of I 879; see, for example, Henrique Espada Lima, "Freedom, Precariousness, and the Law: Freed Persons Contracting out their Labour in Nineteenth-Century Brazil", International Review of Social History, 54 (2009), pp. 39I-4I6. See also Marília Ariza, "Ofício da liberdade: contratos de locação de serviços e trabalhadores libertandos em São Paulo e Campinas (I 830-I 888)” (Master’s thesis in History, Universidade de São Paulo, 20 I 2).
} 
Although slavery continued to exist and property rights associated with it had to be dealt with, the institution had been undergoing a process of change. If, according to Roman law, the statuliberi remained slaves of the heirs until the fulfillment of the condition established in the last will and testament, then, necessarily, the children born of conditionally manumitted mothers had to be considered slaves. The strict application of this principle meant that the children were in a worse position than their mothers, for statuliberi mothers had freedom ensured within a given time, while the children did not have a foreseeable hope of becoming freed. The situation seemed cruel and contradicted the present state of civilization; actually, Caetano Soares implied that the ideas of Teixeira de Freitas would have made perfect sense if he were living in ancient Rome. ${ }^{35}$

Malheiro and Soares then returned to the question, which Freitas had previously raised, of whether conditional manumission could be compared to a labor contract. They argued that the obligation to render services did not in itself mean a state of bondage. For instance, it would be absurd to consider as slaves the colonos - free agricultural laborers - hired under the contractual conditions established in the law of 1837 . Furthermore, if the statuliberi did not enter into the new situation of their own initiative, judicial or notarial officials did so on their behalf, thus assuring them the benefit of the contractual relation pertaining to conditional manumission.

Malheiro and Soares maintained that Teixeira de Freitas believed that all workers under obligation to render services had to be conceived of as in bondage. They deemed such a conception an error originating in a refusal to see the distinction between the slave as property and the slave as someone able to perform labor. These two things were not the same, as was clear from the fact that a proprietor could have a legal title to a slave and still grant to someone else the right to enjoy the labor such a captive was able to provide. Conversely, a person could be nominally free, such as an agricultural laborer hired under the law of 1837 , and still have to perform labor under a contract that established criminal sanctions for its breach. In sum, since they conceived of labor relations originating in conditional manumission as not being the continuation of bondage, Soares and Malheiro defended the position that in the new, civilized world in the making, a person could be both nominally free and subjected to forms of compulsory labor. ${ }^{36}$ This was a contention that would be taken up again in the future, under different political circumstances, to defend the postponement of the abolition of slavery, or, more precisely, to enact an abolition law that would subject freed people to further years of compulsory labor, as we shall see. 


\section{SLAVES GO TO COURT}

In presenting his selection of judicial controversies regarding the status of children of conditionally manumitted women, J. Caroatá did not choose to offer them chronologically, or according to their length. Instead, he opened the section with the reasons alleged by a solicitor, on behalf of the pardo Aquilino, in a civil suit in which it was argued that he had been born free because his mother had been born the daughter of a conditionally manumitted woman (that is, Aquilino's grandmother). ${ }^{37}$ In this case, then, the justification for freedom originated in events two generations back in time. Caroatás decision to begin his compilation with such a document may not have been accidental. In fact, had he followed a mere chronological order or reasoned according to the importance of the characters involved, he would have begun the volume with the debates in the Institute of Brazilian Lawyers. On the one hand, his editing decision may suggest the importance of the presence of slaves in court struggling for freedom in order to understand the outcome of juridical controversies regarding slavery at the time. On the other hand, the long period which elapsed between the fact that originated the alleged right to freedom and Aquilino's actually going to court to claim such a right suggests the limits and difficulties bonded people had to deal with in appealing for justice. ${ }^{38}$

Freedom suits found in Brazilian archives are often lengthy documents that may contain hundreds of pages if they include appeals to higher courts. Such was the case with the preto (black) Pompeu, who filed his initial petition for freedom with a local judge in Rio in August I 860, having to wait for a final decision until July I $863 .{ }^{39}$ "Pompeu said, through his guardian (curador)", as was the usual way of opening such texts, that he had a right to freedom because his mother, Lauriana, had given birth to him and to his siblings after having received conditional manumission from her master. Lauriana had the obligation "to serve only for as long as her liberator lived, and she would become absolutely free from the day of

\section{Ibid., pp. 5-10.}

38. Letícia Graziele Basílio de Freitas, "Escravos nos tribunais: o recurso à legislação emancipacionista em ações de liberdade do século XIX” (B.A. thesis in History, UNICAMP, 20I2). Available online: http://www.bibliotecadigital.unicamp.br/document/?code=00094242 5 \&opt=I . 39. O preto Pompeu (plaintiff), and João Araújo Rangel (defendant), petition for freedom, n. 2665, maço 923, galeria A, Arquivo Nacional do Rio de Janeiro [hereafter, ANRJ]. I have analyzed this story before in Chalhoub, Visões da liberdade, pp. I23-I 27. For Visões da liberdade I had found only the proceedings pertaining to the lower court (2a. Vara Cível); very recently, I found the appeals to the higher court (Tribunal da Relação da Corte), which contain, at the beginning, a transcript of the proceedings in the lower court; microfilm copy, AN 84.0.ACI.096, made from the originals belonging to the Arquivo Nacional and deposited at the Arquivo Edgard Leuenroth, UNICAMP. 
his death".$^{\circ}$ Lauriana's master had died in 1842 and she had been free since then; Pompeu, however, remained in bondage and lived now in another household. The curator argued that Pompeu should have been deemed free together with his mother, beginning on the day of her master's death.

The judge decided to take the slave away from his alleged proprietor's house for the duration of the court proceedings and to put him under "deposit", as was said, with a citizen indicated by the judge. The curator appended a certified copy of the conditional letter of manumission granted to Lauriana. He had obtained the certified copy of the letter of liberty from another appeal for freedom, filed by Pompeu's siblings against their supposed proprietors. One of the persons who testified on Pompeu's behalf mentioned that his mother, Lauriana, still lived in the company of her former mistress's family - more precisely, with the former mistress's son-in-law. The son-in-law, Pedro do Couto, acted as curator on behalf of both Pompeu and his siblings in the two civil suits seeking to free Lauriana's children. ${ }^{4 \mathrm{I}}$

Lauriana was then in her fifties, and it seems that the family she had served for her whole life decided to go to court to seek the freedom of her children. Nonetheless, we may hypothesize that the family itself had originally held her children as slaves and sold or dispersed them through inheritance. We will probably never know how Lauriana managed to obtain the support of her former master's family to seek the freedom of her offspring. We may suspect that decades of seemingly faithful service and subjection to labor exploitation had done the trick, together with the vulnerability suggested by the enslavement of her children and the fact that she continued dependent on and living with the seigneurial family in old age. ${ }^{42}$

However, Pompeu probably had his own reasons to struggle for freedom at that particular time. He had become a valuable slave. When he was nine or ten years old, his master had made him an apprentice tailor. He seemed to be also appreciated as a page, setting tables and serving family meals. Lately, he had learned to work as a coachman. Pompeu filed his petition for freedom

40. Lower-court proceedings (2a. Vara Cível), leaf 3 , front side; the quoted passage reads as follows in Portuguese: "a servir somente durante a vida de seu libertador, e ficaria absolutamente livre, desde o dia em que ele falecesse".

4I. In the lower-court papers, the initial petition of the plaintiff and accompanying documents run from leaves 3 to 10 , both sides of each leaf; the copy of the letter of manumission is on leaves 8 and 9 . Pedro do Couto appears as one of the persons authorized to file on Pompeu's behalf on leaf Io. The witness who mentions Pedro do Couto as Lauriana's former mistress's son-in-law is Edwiges Godinho, born in Rio de Janeiro, thirty years old, widow, illiterate, "vive de seus bens" (that is, of income derived from her properties); testimonies appear in sequence beginning on leaf 44 .

42. The practice of reducing to slavery the children of slave women who were freed but remained dependent on the master's family seemed relatively common. For other cases, see, for example, Odorico (plaintiff), petition for freedom, Juízo Municipal da Segunda Vara do Rio de Janeiro, no. I, caixa 523, galeria C, I 862, ANRJ; Teresa Maria da Hora (plaintiff), petition for freedom, Tribunal da Relação do Rio de Janeiro, no. 8 I I 8, caixa 2, I869-I 872, ANRJ. 
when there appeared to be much business speculation around him in the lively slave market of the Empire's capital. João Rangel, the defendant in the petition for freedom, adopted as his first line of defense the allegation that he had just bought the young man, mentioning the names of two previous proprietors of Pompeu, therefore arguing that the freedom suit had to be filed against the person who had sold the slave to him. He gave details of the transaction and appended a letter received from the previous owner that included information on the expectations Pompeu had himself. João Rangel was looking for a slave to work for him as a coachman. Doctor Gonzaga Bastos learned of his need and offered Pompeu to him. The two men talked, negotiated the price, and agreed that Rangel as a potential buyer would have Pompeu examined by a medical doctor.

It is not possible to know whether Rangel also tested the slave's skills as a coachman, although this was often the case in such transactions in Rio at the time. In any case, the seller made it clear that, despite his other skills, Pompeu insisted that he wanted to work as a coachman and this was the reason given to sell him - Doctor Bastos did not have a carriage. Pompeu could keep the brand-new boots and coat that Doctor Bastos had recently bought him, although the latter would go without buttons because those had the doctor's initials. The price of the transaction was high. João Rangel complained that, although he had already paid the total amount, Doctor Bastos had not given him the documents proving his ownership of Pompeu and the payment of due taxes on slave property. Therefore, Rangel said that he had decided to start legal proceedings against Doctor Bastos, to recover the amount paid and return the slave to him, when he learned of Pompeu's petition for freedom. ${ }^{43}$

The story is fascinating in its details and complexities. On the one hand, it suggests the vulnerability of bonded people who received conditional manumission. Their situation was very uncertain, especially in the case of freedoms promised in last will and testaments and in letters of manumission by causa mortis - that is, those in which the donation of liberty depended upon the master's death - because they could be revoked in practice at any time by the proprietor, sometimes unceremoniously by just selling the captive. ${ }^{44}$ Furthermore, as was the case with Lauriana, it seemed common to see conditional manumission as the continuation of bondage until the fulfillment of the condition, entailing that the children of statuliberi women

43. The expectations and anxieties regarding their sale often led slaves to revolt, commit crimes, and file petitions for freedom. For several such cases, documented in civil and criminal trial records, see Chalhoub, Visões da liberdade, especially ch. I.

44. Despite the wealth of studies on manumission in Brazilian slavery, as was mentioned above, works focusing on the experience of conditional manumission are still rare. For a recent study which seeks to analyze the masters' perspective as it appears in last will and testaments, see Alessandra Pedro, "Liberdade sob condição: alforrias e política de domínio senhorial em Campinas, I $855^{-1} 87$ I" (Master's thesis in History, UNICAMP, 2009). 
remained in slavery. The threat of revocation of freedom probably ensured the faithfulness and dependence of the captive; in addition, it may explain the careful strategic calculation involved in choosing the time to go to court and struggle for freedom. On the other hand, it would be wrong to suppose that slaves regarded passively the unfolding of family arrangements, business transactions, and court cases that decided their fate. Lauriana found ways of obtaining allies in her former master's family. Pompeu had learned many of the skills implied in urban slavery in Rio at the time, skills which might be labelled as "political", so he had made himself valuable to his masters and managed to let them know of his expectations. In any case, as the legal battle that followed suggests, the general political context of the I860s, with slave emancipation increasingly on the agenda, helps to understand why Lauriana and Pompeu had then a better chance of achieving their aims. ${ }^{45}$

Besides alleging that the petition for freedom should have been addressed to Pompeu's previous owner, instead of to himself, João Rangel also argued, predictably, that the statuliberi were not freed until the fulfillment of their conditions. In other words, Lauriana remained in slavery when she gave birth to Pompeu, so the boy was a slave. Challenged to defend this argument further on several occasions in the following years, Rangel's lawyers tried two related paths. First, they proposed a careful reading of the letter of liberty granted to Lauriana in order to determine what had been the will of her master. The letter said in one passage that Lauriana should "be [or remain] a captive only during the life" of the master, supposedly meaning that the master thought of her as a slave for as long as he lived. ${ }^{46}$ Second, they sought to define the freedom conceded to Lauriana as causa mortis. According to this reasoning, the intention of Lauriana's master had been to let the crioula (a black slave born in Brazil) know that "if she continued to serve him well, she would become free upon his

45. The participation of slaves in the country's legal culture has been an important theme in the historiography of Brazilian slavery for almost three decades; for early examples, see Silvia H. Lara, Campos da violência: escravos e senhores na capitania do Rio de Janeiro, I750-I808 (Rio de Janeiro, I 988); Chalhoub, Visões da liberdade; Hebe Mattos, Das cores do silêncio: os significados da liberdade no sudeste escravista - Brasil, século XIX (Campinas, 20I3; ist edn, I995); Keila Grinberg, Liberata - a lei da ambiguidade (Rio de Janeiro, 1994). For a volume that gathers several of the most important Brazilian authors in the field and offers a very useful analysis of the state of the art in its introduction, see Silvia H. Lara and Joseli M. Mendonça (eds), Direitos e justiças no Brasil. Ensaios de história social (Campinas, 2006). Also, the studies of Rebecca Scott have been very important: Slave Emancipation in Cuba: the Transition to Free Labor 1860-1899 (Princeton, NJ, 1985); Degrees of Freedom: Louisiana and Cuba after Slavery (Cambridge, MA, 2005); Scott and Hébrard, Freedom Papers. See also Alejandro de la Fuente, "Slave Law and Claims-Making in Cuba: the Tannenbaum Debate Revisited”, Law E History Review, 22 (2004), pp. 339-369.

46. Lower-court proceedings (2a. Vara Cível), leaf 35; the quoted passage reads as follows in Portuguese: "somente seja cativa durante a vida dele outorgante". 
death". ${ }^{47}$ The strategy for slave control made explicit here could be effective only if the master retained the right to revoke the promised freedom as he wished. This situation seemed quite different from that of freed persons already in full possession of their freedoms, who theoretically could only have their liberties revoked if they showed ingratitude to former masters. ${ }^{4}$

Pompeu's defenders replied that Rangel's lawyers had interpreted the cited passage of Lauriana's letter of liberty out of context. To begin with, the document carried a title, which was "deed of conditional liberty" (escritura de condicional liberdade), to emphasize from the beginning that the donation of freedom occurred at the very moment of formalizing it. The assumption of a conditional letter of manumission was that the grantee would exercise her or his judgment to fulfill the obligation there stated; the outcome depended on his or her will, meaning that the person "was released from the position of a slave". The liberty thus granted was not causa mortis, but intervivos - that is, it became immediately effective. Of course, it could be revoked by ingratitude, as could all manumissions until the law of I 87 I prohibited such a possibility, but Lauriana's freedom had never been revoked and this was not a point under consideration. Although Pompeu's defenders added other, procedural, reasons to argue that the liberty granted Lauriana was intervivos, the thrust of their argument was the contention that the condition imposed on the grantee destroyed the fiction of the slave as a thing, bestowing upon her or him the capacity to reason and decide on a course of action. In this the argument resembled the one presented by Perdigão Malheiro and Caetano Soares at the Institute of Brazilian Lawyers in 1857 , for they deemed conditional manumission a form of labor contract because it depended on the will of the person being freed.

Pompeu's lawyers and solicitors did not cite the debates of 1857 in their petition for freedom, neither did they compare conditional manumission to a labor contract. However, the sentence passed by the local judge, Luiz Alvares de Azevedo Macedo, in November I 861, to be confirmed twice in higher courts, recalled in part the politically charged atmosphere of the i 857 debates at the Institute. After summarizing the allegations of each party, the judge said that he based his decision on the provisions of law as well as "on the humanitarian principles derived from the enlightenment of the century". $\mathrm{He}$ proceeded to say that João Rangel's argument that the petition should have been directed against Pompeu's previous master did not make sense because Rangel exercised effective "possession and dominion over the object" - that

47. Lower-court proceedings (2a. Vara Cível), leaf 35; the quoted passage reads as follows in Portuguese: "que se bem o continuasse a servir, por sua morte ficaria liberta". Allegations of the defendant in the lower-court volume begin on leaves $2 \mathrm{I}$, then 34 ; in the higher-court volume, there are allegations beginning on leaves $3 \mathrm{I}$ and 70 .

48. Although masters retained the right to revoke manumissions (conditional or not) until the law of i 87I, some freed people were more vulnerable to re-enslavement than others; see Chalhoub, "The Precariousness of Freedom in a Slave Society", pp. 4I 8-420. 
is, the slave - when Pompeu went to court. Next, he agreed with Pompeu's defenders regarding the freedom of the children born of conditionally manumitted slave mothers. Furthermore, he did so with an embattled tone, dismissing the reasoning of Rangel's lawyers as "sophistic".

The content of the judicial sentence seemed so obviously politicized that Rangel's lawyers included a protest against it in their appeal to the higher courts. They said that the local judge had reached his decision "upholding the desired emancipation", using "an academic style instead of a forensic one" - meaning that the politicization of the subject pertained to lawyers' professional associations and schools of law, not to the courtrooms. In fact, a lawyer named Alvares de Azevedo attended the debates at the Institute in I 857 ; furthermore, a member named Luiz Alvares de Azevedo Macedo participated in the editorial committee of the periodical published by the Institute and was the institution's secretary. Therefore, it seems that this very same person, who had closely followed the I 857 debates, served also as judge in Pompeu's petition for freedom. ${ }^{49}$

The arguments presented in Pompeu's case and the sentence of the local judge, who very likely had also attended the debates in I 857 , suggests the continuity of political meanings commonly associated with conditional manumission into the 1860 - namely, that defenders of slave emancipation seized upon it when struggling for their cause. The situation would begin to change as early as I87i, during the debates leading to the Free Womb Law.

\section{THE POLITICS OF AMBIGUITY}

The politicization of slave motherhood and conditional manumission, issues that converged on the question of the condition of children born to conditionally manumitted women, was a central aspect of debates that led to the slave emancipation law of i87 I (also called the Free Womb Law). Perdigão Malheiro may be credited with having forwarded the cause by a speech in the Institute of Brazilian Lawyers on 7 September $1863 .{ }^{50} \mathrm{He}$ argued that property of slaves was illegitimate and that it contradicted natural law. In the past, enslavement occurred as a consequence of the master's will, imposed by coercion or violence. In the present, it had become

49. I failed to write down the name of the judge when I read the lower-court proceedings in the mid-I980s; the transcription of the sentence and the name of the judge appear in the higher-court volume, leaf 28. For the confirmation of the presence of a lawyer called Alvares de Azevedo in the I 857 debates at the Institute of Brazilian Lawyers, see Caroatá, Apanhamento, p. 3i. For Luiz Alvares de Azevedo Macedo as a member of the editorial committee of the periodical published by the Institute and as the institution's secretary see, respectively, Revista do Instituto da Ordem dos Advogados Brasileiros. Ano II, Tomo II, n. 4, October to December I863, p. I63 and Ano II, Tomo II, n.3, July to August I863, p. I 2 I.

50. A.M. Perdigão Malheiro, "Illegitimidade da propriedade constituída sobre o escravo - Natureza de tal propriedade - Justiça e conveniência da abolição da escravidão; em que termos", Revista do Instituto da Ordem dos Advogados Brasileiros, Ano II, Tomo II, n.3, July to August I863, pp. I 3 I-I 52. 
Manumission, Labor Contracts, and Slave Emancipation in Brazil I8 I

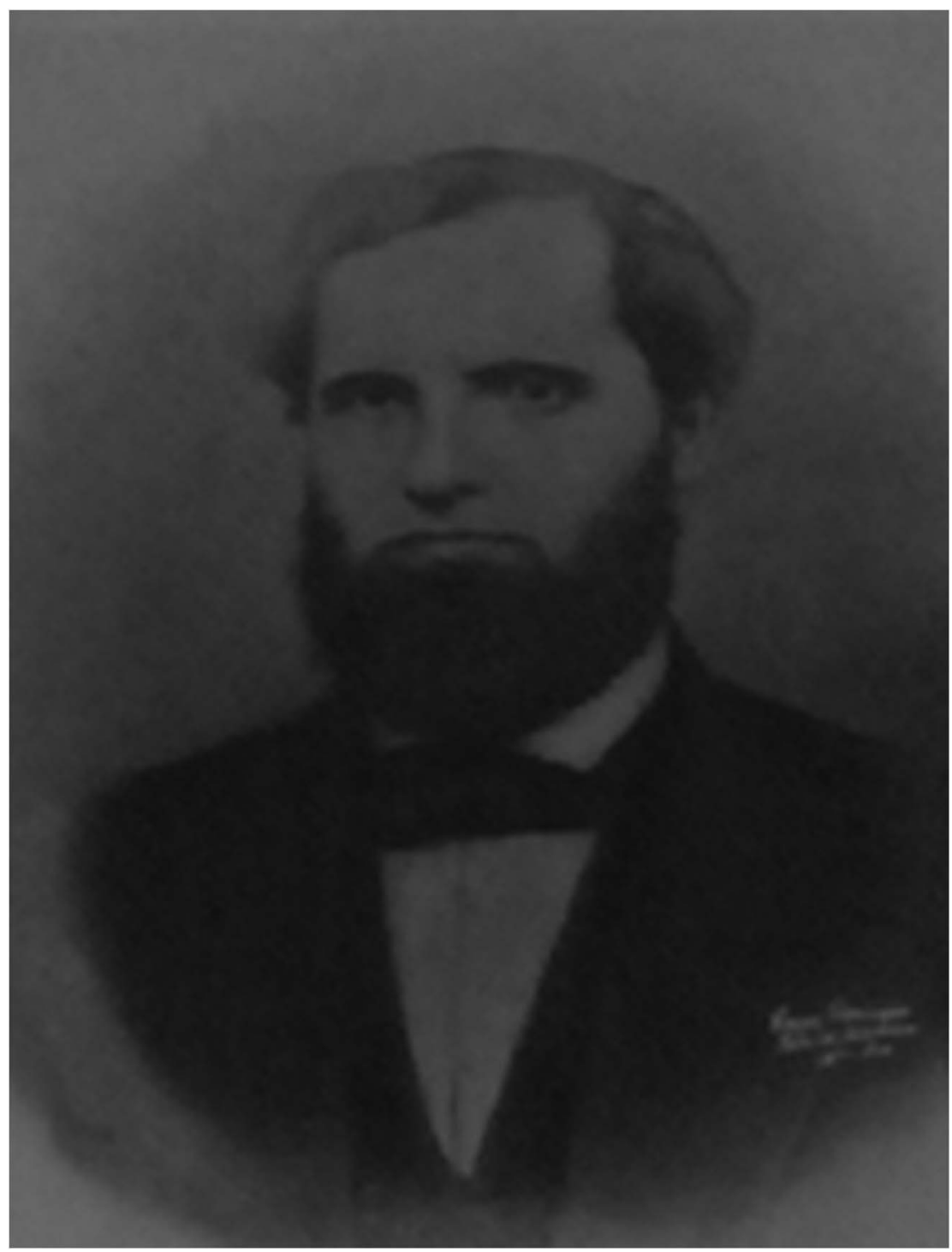

Figure 3. Perdigão Malheiro.

Instituto dos Avogados Brasileiros; http://www.iabnacional.org.br/article.php3?id_article=2059

a result of the legislators' arbitrariness. Bondage passed from one generation to another, in perpetuity, by heredity, based on the Roman principle partus sequitur ventrem. Mentioning several examples of countries that had abolished slavery during the nineteenth century, he suggested that the Brazilian parliament enact a bill declaring free the offspring of slave women. 
He proceeded to recite the hymn of freedom according to the usage of the times: slave emancipation would allow the country "to join the great intellectual and moral movement of the nineteenth century, $[\ldots]$ advancing towards civilization", achieving the "extermination" of an institution that caused "the degradation of the people, the depravation of customs, the backwardness of industry", and so forth..$^{\text {s }}$

Perdigão Malheiro also returned to the theme of the statuliberi in his massive study of Brazilian slavery published in I866-i 867. Perhaps still brooding over Teixeira de Freitas's contention that he had not mastered Roman law, he presented a detailed account of the problem in Roman codes. He sought to demonstrate that there had been an "evolution" regarding the subject in ancient codes. At first, the law deemed the statuliber fully a slave of the heir for as long as there was a pending condition on his or her freedom. Later, there appeared "a preponderance of liberty", with the prohibition of torture and whippings against conditionally manumitted slaves and the admission of their pleading in judicial cases. Nevertheless, as Perdigão Malheiro admitted, the children born of statuliberi slave mothers continued always to be considered slaves of the heirs. ${ }^{52}$

Perdigão Malheiro proceeded with his "work of reconstruction" of the legal aspects regarding conditional manumission by seeking to specify what happened when a master freed a slave. Traditionally, jurists conceived of manumissions as donations, but he thought such a view to be mistaken. In manumission, what is the object being donated? Who is the beneficiary? Enslavement had not been a "donation" to the slave; neither could freedom be seen in this way. "The truth of the matter" was that the act of conceding freedom meant that the master "renounced the dominion and power he exercised (against natural law) over the slave, restoring the natural state of freedom in which all men are born". Slavery belonged to the realm of positive law, contradicting the natural rights of slaves; therefore, it did not make sense to think of masters "donating" freedom to their captives. ${ }^{53}$

Then what happened when a slave received conditional manumission? It could be alleged that the slave's "natural state of manhood" remained suspended until the fulfillment of the condition. Malheiro stated that such an opinion resulted from "confusion", from refusal to abandon "the terrain of fictions" that the institution of slavery had created. According to him, upon receiving a conditional manumission a slave "is promptly restored to his natural condition of a man and a person", despite the fact that the full enjoyment of liberty remained postponed. His imaginary opponent appeared again to say that it seemed absurd that someone repossessed his or her natural

5 I. Perdigão Malheiro, "Illegitimidade da propriedade constituída sobre o escravo", p. I 5 I.

52. Idem, A escravidão no Brasil: ensaio histórico, jurídico, social, 2 vols (Petrópolis, 1976); for the passage mentioned, see I, pp. I I 4-I I7.

53. Idem, A escravidão no Brasil, I, p. I I 8. 
freedom and continued devoid of it, depending upon a certain period of time or a particular event to become fully free. Perdigão Malheiro explained that he considered the situation of conditionally manumitted individuals to be similar to that of minors, "who depended upon a certain event or a period of time to be emancipated and thus enjoy full civil rights and liberties". 54

It is noteworthy that, in contrast to the debates of I857, conditional manumission is not compared to a labor contract here, with the accompanying rhetoric of people able to reason and to decide on a given course of action - regardless of the notion that the choices to be made available consist of new forms of unfree labor. The approximation of conditionally manumitted persons to minors seems to underline instead their unpreparedness for freedom, thus echoing in the Brazilian context a central theme of passages from slavery to post-emancipation societies also present elsewhere. ${ }^{5}$ Therefore, it seems paradoxical (but, at second view, perhaps not surprising) that Perdigão Malheiro changed his mind about the idea of pursuing gradual emancipation by means of freeing the children born of slave women. For reasons that are not clear and may include a petty revenge for not having been invited to become a minister of state, he opposed the Free Womb Law (1871)..$^{56}$

Interestingly, opponents of the law, representatives of the coffee economy prominent among them, adopted the view that the statuliberi must be considered free at the moment they received the promise of freedom. They did so with the intention of garnering political support against the bill through the spread of fear among planters. One of their arguments was that, since the bill established an emancipation fund which could eventually benefit every captive, the law would entail the recognition that all bonded people became statuliberi, just awaiting the fulfillment of a condition (enough funds for slave property indemnification) to achieve full freedom. The consequence of this would be a situation in which plantation slaves could not be disciplined and punished as slaves any more, nor could they be subjected to commercial transactions and other property deeds pertaining to slavery.

The argument appeared again during the political debates that would result in the law of 28 September i 885 , which freed slaves who reached the age of sixty. Opponents of the bill alleged that it meant attributing to all existing slaves the condition of statuliberi. In other words, every slave would have a right to freedom to be achieved after a period of time - that is, when he or she became sixty years old. The parliamentary opposition would then take up the arguments present in Perdigão Malheiro's book to

54. Ibid., p. I 20.

55. See, for instance, the "Introduction" in Frederick Cooper, Thomas Holt, and Rebecca Scott, Beyond Slavery: Explorations of Race, Labor, and Citizenship in Postemancipation Societies (Chapel Hill, NC [etc.], 2000), pp. I-32.

56. Sidney Chalhoub, Machado de Assis, historiador (São Paulo, 2003), pp. I86-1 87. 
say that conditionally manumitted slaves were already free, and therefore they could not be subjected to property transactions pertaining to slavery. In turn, defenders of the bill would refer to the I 857 debates to cite Teixeira de Freitas and maintain that the statuliberi continued in full bondage until the fulfilment of the condition established for manumission. As is clear from a comparison of political discourses regarding conditional manumission in the I860s and I880s, the same legal arguments had acquired completely different political meanings. ${ }^{57}$

Perhaps still more surprising is the manner in which the same legal controversies reappear in September I887, in the wake of the social crisis and disorganization of labor relations in the coffee plantations, including the widespread slave flight mentioned at the beginning of this article, that would lead to abolition in May of the following year. ${ }^{88}$ The parliament was in its final sessions of the year when the crisis of slavery became the focus of heated debates in the Senate. Antonio Prado, a prominent senator of the Conservative Party and a representative of coffee planters from the province of São Paulo, seems to have turned against his own constituents: slaves in Campinas, a major coffee-growing area in the province of São Paulo, had been running away from rural properties in massive numbers. Planters sent a petition to the Chamber of Deputies, there presented by Andrade Figueira, a deputy from the province of Rio de Janeiro and prominent defender of slavery, complaining that they had not been receiving proper assistance from the provincial and imperial authorities to maintain discipline in the slave quarters. Antonio Prado brought the theme to the Senate floor, asking that the conservative cabinet inform parliament about what the President of the province of São Paulo had been doing to restore "public order on the occasions of massive flights of slaves from the plantations in the county of Campinas".59 Antonio Prado's main purpose was to suggest that planters in Campinas should not be waiting for the government to muster the necessary forces to guarantee slave discipline. It was no longer possible to achieve that by the force of the military or police. Planters had to understand that they needed to deal with the situation by themselves and with a different strategy.

57. For the discussion on the statuliberi in I87I and 1885 , see Eduardo Pena, Pajens da Casa Imperial, ch. 3 ; for an in-depth study of the 1885 law and its application, Joseli Mendonça, Entre a mão e os anéis: a lei dos sexagenários e os caminhos da abolição no Brasil (Campinas, 1999).

58. My account of events in September 1887 is based on the reading of the Gazeta de Noticias, a daily paper published in Rio de Janeiro. Because discussions in the Senate became the focal point of the political crisis regarding slavery at that particular moment, the Gazeta is an essential source. The periodical published the proceedings of the Senate and commented extensively on what happened there. It opposed the conservative cabinet then in power. For a detailed study of slave resistance in the province of São Paulo in the I 880 s, including the massive slave flights beginning in I887 and continuing until abolition, see Maria Helena Machado, $O$ plano e o pânico: os movimentos sociais na década da Abolição (Rio de Janeiro [etc.], 1994).

59. Section entitled "Diario das Camaras", Gazeta de Notícias, I 8 September I 887, p. I. 


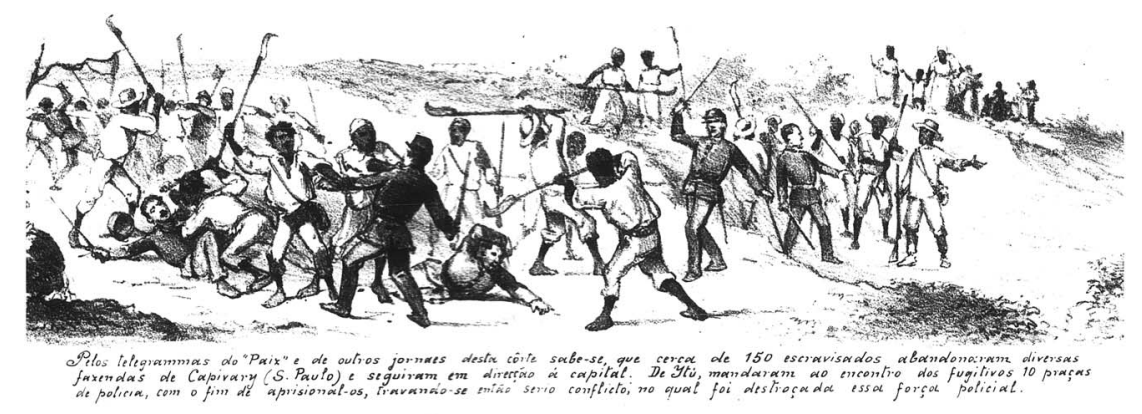

Figure 4. Revista Illustrada, I 2th year, no. 468 (Rio de Janeiro, 22 October I 887), p. $4 \cdot^{60}$ Translation of cartoon text: "According to telegrams from O Paiz [a daily paper in Rio] and other newspapers in this Court, iso enslaved people left several plantations in Capivary (province of São Paulo) and walked to the capital. In Itú [a town in the interior of the province of São Paulo] Io policemen attempted to arrest them; there was a serious conflict, in which the police force was badly defeated."

According to Antonio Prado, many slave owners in the province of São Paulo had successfully prevented massive flights from their properties by granting conditional manumission to their slaves. These freedoms were given upon the condition of continued service for a period of time - it appears that Prado himself recommended three years. Examples of such concessions of freedom abounded at that particular time, announced with self-interested pomposity in daily papers and saluted by journalists and readers with what seems to be, retrospectively, a rather hypocritical sense of moral worth. The idea was that the promise of freedom would restore the authority of masters in a moment of crisis in labor relations and instill in slaves the sentiment of gratitude, thus increasing the likelihood that they remain on the plantations while the imperial government decided what to do.

Actually, conditional manumission appeared to inspire many of the proposals presented in the parliament during the turbulent month of September I 887. Senators and deputies drafted several different bills that seem remarkable for what they had in common: the imperial government should enact a law declaring the emancipation of all slaves, who nonetheless would have the obligation to serve their masters for two, three, or five more years. Furthermore, the parliament should urgently pass legislation against vagrancy, thereby creating legal means to force all "free" people to perform forms of labor deemed acceptable or desirable. ${ }^{61}$

6o. On p. 3 of the same issue, there is an article about this episode, and the title is "Greve de escravizados" ["A strike by enslaved people"].

6I. See, for instance, two different bills proposed by senators Taunay and Godoy, section entitled "Elemento Servil", Gazeta de Notícias, 25 September I887, p. I. A similar combination of slave resistance, proprietors' grants of conditional manumission, and discourses on the alleged vagrancy 
Politically, the decline of slavery seemed increasingly irreversible in September I 887. The tipping point may have been the news that Joaquim Nabuco, a famous abolitionist, had been elected to return to parliament as a deputy for the province of Pernambuco. Nabuco defeated a minister of the ruling conservative cabinet in the elections, compelling the minister to resign his post. ${ }^{62}$ The outcome of the elections in Pernambuco dramatized the increasing political isolation of the president of the cabinet, Cotegipe, who resisted any suggestion that he should act promptly to abolish slavery while it was perhaps still possible to do so in a controlled manner. This is why a conservative senator such as Antonio Prado became critical of the cabinet: it was the perception that postponing the abolition of slavery meant losing control of events. Perhaps he believed that conditional manumissions granted by private masters, followed by an emancipation bill that required freed persons to render three more years of forced labor, would suffice to detain the massive flight of slaves from coffee plantations. Alternatively, slave labor did not matter much to him any more. By September i 887 , Antonio Prado and coffee planters close to him had put in place a system of subsidized immigration that had already started to bring thousands of Italians to the province of São Paulo. ${ }^{63}$

Meanwhile, in the very same eventful month of September I887, members of the Institute of Brazilian Lawyers (IAB) returned to the subject of the condition of the statuliberi. More precisely, they discussed whether the law of 1885 had made every person still enslaved in the country a statuliber, which naturally led again to the question of what conditional manumission really meant. At this point, it is unnecessary to reintroduce the arguments there presented - they followed the patterns established in the I 850 s. It suffices to say that, on I September, José da Silva Costa read a report on the subject, approved almost unanimously by his peers, saying that in the case of the statuliberi "the limitations imposed by the law do not destroy freedom, inasmuch as contingency does not eliminate essence". ${ }^{64}$ However shallow the philosophical formulation, supported of course by plenty of citations from Perdigão Malheiro's book, it seemed clear that at

of freed people appeared in the province of Bahia in the months before abolition; see Walter Fraga Filho, Encruzilhadas da liberdade: histórias de escravos e libertos na Babia (I 870-1910) (Campinas, 2006), especially chs 3 and 4.

62. For a good-humored and ironic comment on the repercussions of Nabuco's electoral victory, see the section entitled "Chronica", Gazeta de Notícias, i 8 September I887, p. I.

63. Michael Hall, "Os fazendeiros paulistas e a imigração", in Fernando Teixeira da Silva et al. (eds), República, liberalismo, cidadania (Piracicaba, 2003), pp. I 53-161.

64. Gazeta de Notícias, i7 September I887, p. I. The text appeared soon thereafter; see José da Silva Costa, "Das relações juridicas dos sujeitos à condição de servir, especialmente após a promulgação da Lei n. 3270 de 28 de Setembro de I885", Revista do Instituto dos Advogados Brazileiros. Tomo XI, I 887, pp. I0-52 (includes his reply to a colleague who criticized his text, as we shall see). 
this political juncture resorting to the debate in the Institute in 1857 meant support for the view that abolition should be preceded by a transitional period in which freed people would continue to render compulsory labor. The emphasis here is on the supposed freedom pertaining to the condition of the statuliberi. It seems that most members of the Institute, eight months before further events would lead to full abolition, sought to preclude the possibility of a "radical" (as was said) solution to the problem - that is, the enacting of further legislation on the subject, such as a bill abolishing slavery altogether, without the payment of a monetary indemnification to masters or the rendering of further services by freed people.

The dissonant voice at the Institute on this occasion was Baptista Pereira, who published a pamphlet, dated 30 September i 887, criticizing Silva Costa's piece and his peers' approval of it. ${ }^{65}$ Resorting to the authority of Teixeira de Freitas regarding Roman legal precedent and to the debates preceding the law of $\mathrm{I} 88 \mathrm{~s}$, he argued that it made no sense to seek freedom in the condition of the statuliberi. There existed no such thing as a transitional or intermediary state between slavery and freedom. Quoting Seneca, he deemed the statuliber the monstrum that revealed the horrific and painful truth - a slave remained a slave until freedom came without further requirements or procrastinating clauses. Given the present situation, the only choice left to legislators was "to resolve the problem radically" by simply abolishing slavery. ${ }^{66}$

Thus, we come to a moment in which the political turmoil and the disorganization of labor relations provoked by massive slave flights from coffee plantations made more apparent the political appropriations of the meanings of slavery and freedom. As the crisis deepened in the following months, resulting in the allegedly "radical" solution that Antonio Prado and the members of the Institute sought to avoid - abolition without monetary indemnification to proprietors or further services by freed people decades of social and legal subtleties rooted in the structural ambiguities of conditional manumission seemed to vanish from the political imagination. "Slavery" and "freedom" - or slave labor and free labor - became two opposing, contrasting states, impossible to conceive of as dialectically coexistent given the belief in a supposed law of human evolution that assumed a sure march from one to the other. This retrospective view of past events makes it difficult for us to see spaces of ambiguity and perhaps freedom within slave societies. More importantly, it helps to render invisible the reproduction of bonded labor in modern capitalist societies.

Furthermore, the centrality of conditional manumission in the final crisis of slavery in Brazil reveals a great deal about the expectations of planters for 


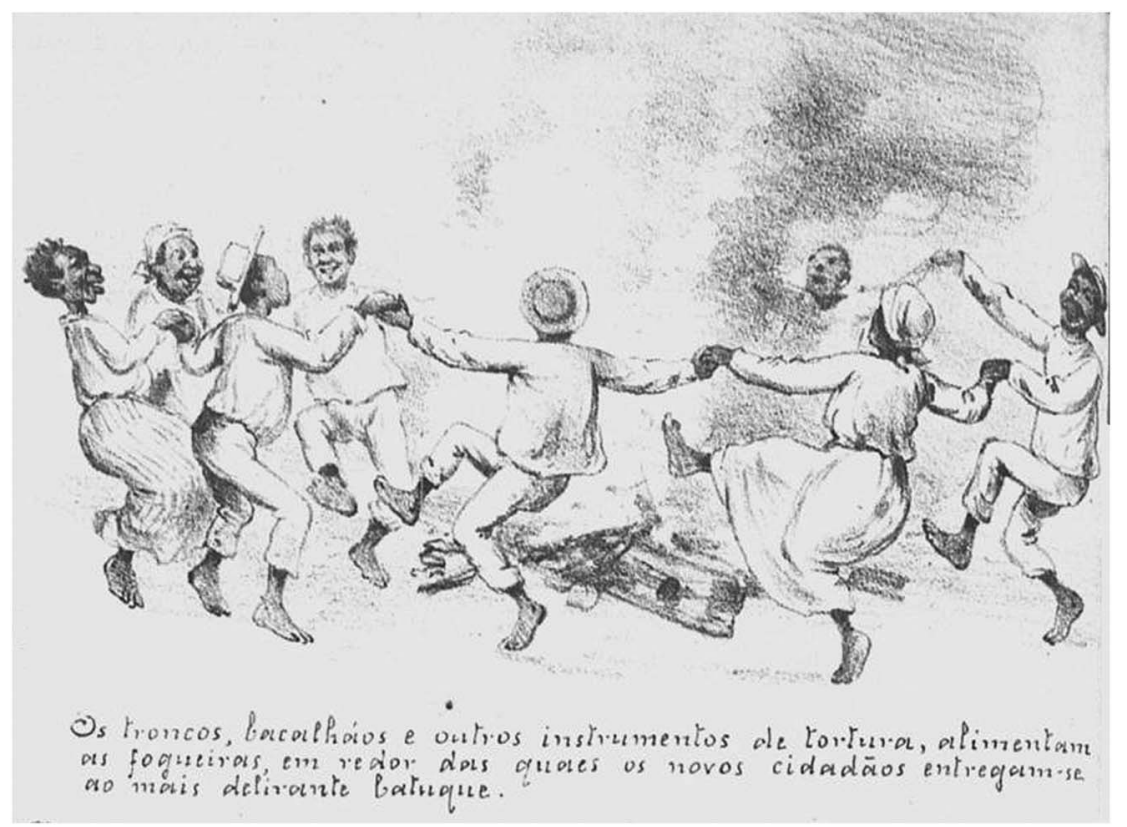

Figure 5. Revista Illustrada, I 3 th year, no. 00499 (Rio de Janeiro, 2 June I 888), p. 4.

Translation of cartoon text: "The stocks, whips, and other instruments of torture now feed the bonfires around which the new citizens dance the most delirious batuque."

the immediate aftermath of emancipation. They struggled to attain two main objectives: first, they wanted continued dependence and faithfulness on the part of ex-slaves, the maintenance of their "moral authority", as they used to say; second, if there was to be a legally regulated labor market, contracts had to restrict the mobility and the autonomy of workers. What actually happened afterwards depended on a number of factors and varied widely according to different regions of the country.

In the coffee-producing regions of São Paulo, (racist) resentment was further exacerbated by the experience of massive slave flight on the eve of abolition (the "general strike" mentioned above), the availability of impoverished Italian peasants in the global labor market, and the capacity of provincial grandees to organize and subsidize European immigration, resulting in the exclusion of ex-slaves from social and economic opportunities in the post-emancipation period. ${ }^{67}$ Elsewhere, the picture that has been emerging slowly in historical studies is more nuanced and diverse.

67. Michael Hall, “The Origins of Mass Immigration in Brazil, I 87 I-I9I4” (Ph.D. dissertation, Columbia University, I969); Verena Stolcke and Michael Hall, "A introdução do trabalho livre nas fazendas de café de São Paulo”, Revista Brasileira de História, 6 (I983), pp. 80-ı 20; George 


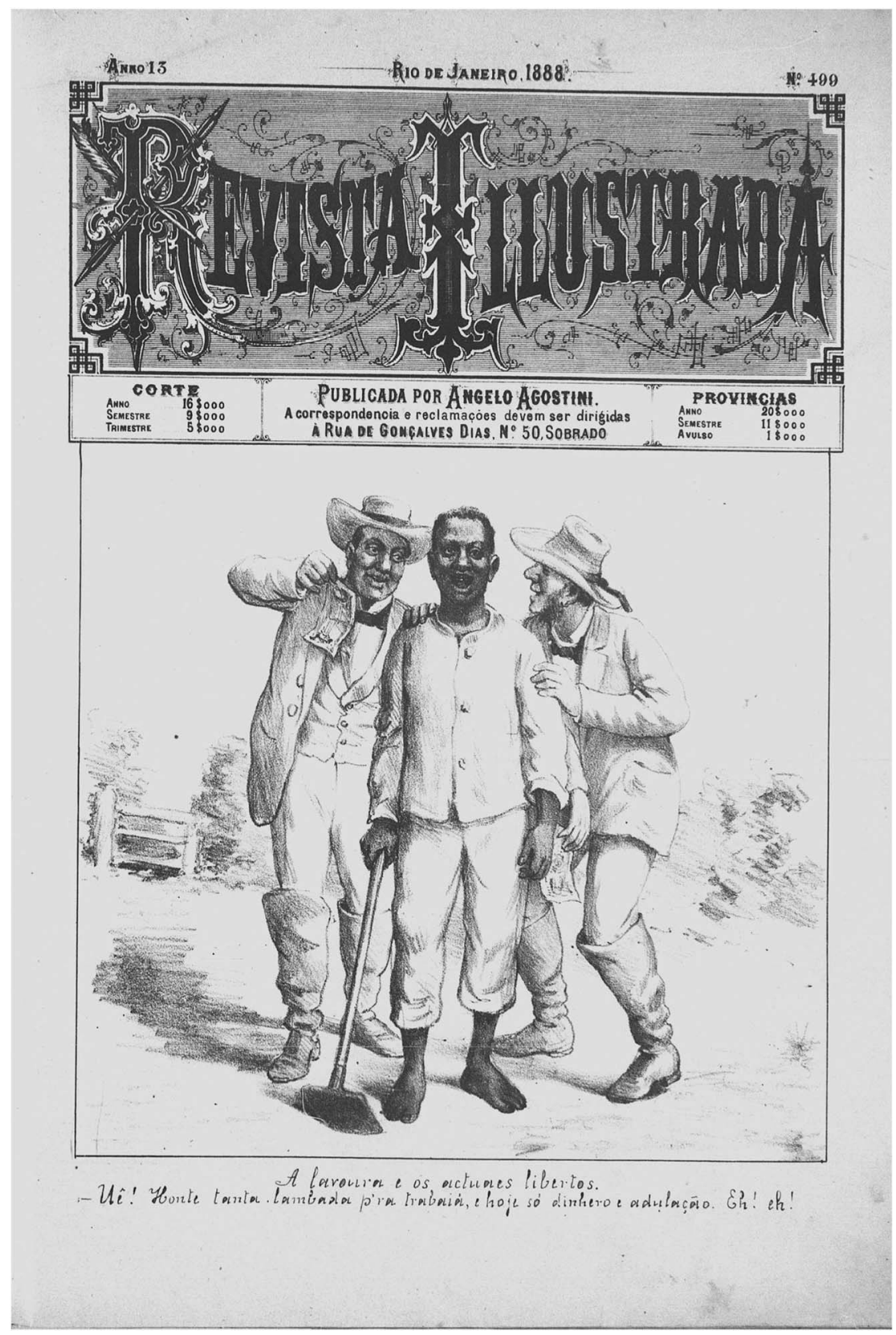

Figure 6. Revista Illustrada, I 3 th year, no. 00499 (Rio de Janeiro, 2 June I 888), cover page. Translation of cartoon text: "The planters and the newly freed. What! Yesterday lots of whiplashes to work, and today only money and adulation. Ha! Ha!” 
There were old coffee areas in the province of Rio that suffered heavy economic losses and desolation; others, dedicated mainly to food production, allowed for some access to land and the growth of small properties; ${ }^{68}$ and there seems to have occurred significant migration of people of African descent to capital cities. ${ }^{69}$ More importantly, with the exception of immigrants in sharecropping and labour service arrangements (the colonato) in the province of São Paulo, and of some sectors of the labor force in major cities, ${ }^{70}$ the labor market continued mostly unregulated for decades to come, with informal arrangements and paternalist strategies of control predominating over contracts and formal labor rights. ${ }^{7 \mathrm{I}}$ Thus the ambiguities of "freedom" and "unfreedom" by no means ended with abolition but continued in different guises - until today.

\section{TRANSLATED ABSTRACTS FRENCH - GERMAN - SPANISH}

Sidney Chalhoub. La politique de l'ambiguité. Affranchissement conditionnel, contrats de travail et émancipation des esclaves au Brésil (dans les années I850-I888).

Bien qu'il semble que les esclaves au Brésil au ige siècle eurent plus de chance d'accéder à la liberté que leurs homologues dans d'autres sociétés esclavagistes aux Amériques, des études montrent également qu'une importante proportion des affranchissements fut accordée conditionnellement au Brésil. La liberté pouvait ainsi dépendre du décès d'un maitre, du mariage de la fille d'un maitre, d'un service continu pendant plusieurs années, etc. Cet article concentre donc sur l'affranchissement conditionnel pour étudier les ambigüités légales et sociales entre esclavage et liberté, prévalant dans la société brésilienne au dix-neuvième siècle. L'affranchissement conditionnel apparut parfois comme une forme de contrat de travail, envisagée dans une situation dans laquelle une personne pouvait à la fois être libre de nom et assujettie à des formes de travail forcé. Pendant la crise finale de l'abolition, en I887-I888, lorsque les esclaves

Reid Andrews, Blacks and Whites in São Paulo, Brazil, I888-1988 (Madison, WI, I99I); Luiz Aranha Corrêa do Lago, Da escravidão ao trabalho livre, Brasil, I550-I900 (São Paulo, 2014).

68. Ana Rios and Hebe Mattos, "Para além das senzalas: campesinato, política e trabalho rural no Rio de Janeiro pós-Abolição”, in Olívia Cunha and Flávio Gomes, Quase-cidadão: histórias e antropologias da pós-emancipação no Brasil (Rio de Janeiro, 2007), pp. 55-78; Hebe Mattos, Ao sul da história: lavradores pobres na crise do trabalho escravo (Rio de Janeiro, 2009); idem, Das cores do silêncio, part IV; for the region of the Recôncavo, in Bahia, see Fraga Filho, Encruzilhadas da liberdade, chs 6 to 9 .

69. For the case of Rio de Janeiro, there is a very detailed study of internal migration and racial inequalities after abolition: Samuel Adamo, "The Broken Promise: Race, Health, and Justice in Rio de Janeiro, I 890-1940” (Ph.D. dissertation, University of New Mexico, I983).

70. Maria Cecília Velasco e Cruz, "Da tutela ao contrato: 'homens de cor' brasileiros e o movimento operário carioca no pós-abolição", Topoi, I I (2010), pp. I I4-I35.

7I. See Ângela de Castro Gomes and Fernando Teixeira da Silva, "Os direitos sociais e humanos dos trabalhadores no Brasil: a título de apresentação", in idem (eds), A Justiça do Trabalho e sua história: os direitos dos trabalhadores no Brasil (Campinas, 2013), pp. I4-16. 
quittèrent massivement les plantations, les maitres accordèrent souvent un affranchissement conditionnel dans une tentative de garantir le travail forcé des personnes qui leur étaient liées pendant quelques années de plus.

Traduction: Christine Plard

Sidney Chalhoub. Politik der Ambiguitität. Konditionelle Freilassung, Arbeitsverträge und die Befreiung der Sklaven in Brasilien (I85oer Jabre bis I 888).

Es hat zwar den Anschein, dass Sklaven im Brasilien des I9. Jahrhunderts bessere Chancen hatten, ihre Freiheit zu erlangen, als Sklaven in anderen amerikanischen Gesellschaften, doch hat die Forschung auch gezeigt, dass ein wesentlicher Anteil der Freilassungen in Brasilien an Bedingungen geknüpft war. Die Freilassung konnte abhängig gemacht werden vom Tod des Sklavenhalters, der Eheschließung durch dessen Tochter, der mehrjährigen Leistung weiterer Dienste usw. Der Beitrag widmet sich Kontroversen um die konditionelle Freilassung und erkundet so die rechtlichen und gesellschaftlichen Ambiguitäten, die den Bereich zwischen Sklaverei und Freiheit in der brasilianischen Gesellschaft des 19. Jahrhunderts prägten. Die konditionelle Freilassung erschien zuweilen als eine Art Arbeitsvertrag und wurde als Zustand aufgefasst, in dem eine Person nominell frei, zugleich aber Formen der Zwangsarbeit unterworfen sein konnte. Während der finalen Krise der Sklaverei, die in deren Abschaffung mündete (I887-ı 888), entschlossen sich Sklavenhalter vor dem Hintergrund einer massenhaften Fluchtbewegung der Sklaven von den Plantagen, häufig zur Gewährung konditioneller Freilassungen, um auf diese Weise die Zwangsarbeit ihrer Untergebenen einige Jahre länger sicherzustellen.

Übersetzung: Max Henninger

Sidney Chalhoub. La política de la ambigüedad. Manumisión condicional, contratos de trabajo y emancipación esclava en Brasil (I850-I888).

Aunque pudiera parecer que en Brasil a lo largo del siglo XIX los esclavos tuvieron mejores oportunidades de alcanzar su libertad que sus iguales en otras sociedades esclavistas del continente americano, los estudios también muestran que una parte bastante significativa de las manumisiones fueron concedidas de forma condicional. Alcanzar esa libertad podía depender de la muerte del amo, del matrimonio de la hija de éste, del servicio continuado durante un número concreto de años, etc. Este artículo se centra en las controversias que se plantean alrededor de la manumisión condicional para explorar las ambigüedades legales y sociales entre esclavitud y libertad que prevalecieron en la sociedad brasileña del siglo XIX. La manumisión condicional aparecía en ocasiones como una forma de contrato de trabajo según lo cual la persona podía ser nominalmente libre y, al mismo tiempo, quedar sujeta a formas de trabajo cautivo. En la crisis final de la abolición, en i 887-i 888, con los esclavos abandonando las plantaciones de forma masiva, los amos a menudo recurrieron a la concesión de manumisiones condicionadas en un intento de garantizarse el trabajo forzado de sus cautivos durante unos cuantos años más. 